\title{
TOOTH TRANSPOSITION: TWO CASE-REPORTS AND LITERATURE REVIEW
}

\author{
TRANSPOSIÇÃO DENTÁRIA: DOIS RELATOS DE CASOS E REVISÃO DE LITERATURA
}

\section{Camila Alves FERRI 1; Laura de Campos HILDEBRAND ${ }^{2}$}

\author{
1 Undergraduation Student, School of Dentistry, Federal University of \\ Rio Grande do Sul (UFRGS), Porto Alegre, Rio Grande do Sul, Brazil. \\ 2 Assitant Professor, Department of Oral Patology, School of \\ Dentistry, Federal University of Rio Grande do Sul (UFRGS), Porto \\ Alegre, Rio Grande do Sul, Brazil.
}

\section{Corespondência}

Nome: Laura de Campos Hildebrand

Email: lauracamposh@gmail.com

Endereço: Rua Ramiro Barcelos, 2492 Sala 503

Porto Alegre, Rio Grande do Sul

Zip Code: 90035-003

\begin{abstract}
Tooth transposition is a rare developmental disorder in which a normal tooth erupts in an inappropriate position. The change in position occurs between two adjacent teeth within the same quadrant. In this article, two cases of tooth transposition involving mandibular molars are described. To our knowledge, this is the first article describing bilateral TT between first and second mandibular molars. Patient 1 presented with bilateral transposition between first and second mandibular molars. In addition, giroversion of the first molars was observed. Patient 2 presented with unilateral transposition between the mandibular left molars. Because this tooth disorder does not affect quality of life, both patients declined to seek dental treatment. Out of the 153 cases of tooth transposition found in the literature, 141 occurred in the maxilla and 73 were on the left side, 94 of these cases involved the canine and first premolar; 44 involved the canine and lateral incisor; 6 involved the canine and central incisor; and only 1 involved the first and second molar. The majority of tooth transposition cases occurred in women (102 cases). In literature, tooth transposition is a poorly-documented condition. Consequently, this report seeks to contribute to the existing information in the literature on this disorder, since this is the first article describing a case of bilateral TT affecting mandibular molars. Moreover, we also suggest a new categorization for dental transposition.
\end{abstract}


Keywords: Dental transposition. Tooth abnormalitie. Tooth

transposition.

\section{INTRODUCTION}

Tooth transposition (TT) has been described as an interchange in the position of two permanent teeth within the same quadrant of the dental $a_{c h}{ }^{1}$. It is a unique form of ectopic eruption wherein a permanent tooth develops and erupts in a position normally occupied by another permanent tooth ${ }^{2}$. TT is considered a rare anomaly with uncertain etiology that often represents a challenge for the clinician ${ }^{1}$. A literature search was conducted on PubMed, Scielo, and Bireme databases using the term "tooth transposition," and 176 studies published in the last 15 years were found. However, only 62 reports in the English language, that described clinical cases of TT in humans, met the inclusion criteria (these articles are listed in Table 1).

TT can occur at any age and is usually diagnosed during clinical and radiographic examination, prior to orthodontic treatment. The distribution of TT cases by sex varies according to the geographical location $^{1,65,66}$. It can affect the maxillary or mandibular dentition, unilaterally or bilaterally ${ }^{66}$. However, unilateral transpositions are reported more frequently than bilateral transpositions, and the left side is more frequently involved than the right side $^{67}$. In addition, it is more common in the maxilla ${ }^{6}$ (between the canine and first premolar) than the mandible where fewer teeth groups are affected (between the canine and lateral incisive $)^{17,69}$. To our knowledge, this is the first article describing bilateral TT between first and second mandibular molars.

Five different variations of maxillary TT have been described ${ }^{69}$. They are classified as Canine-first premolar (Mx.C.P1), Canine-lateral incisor (Mx.C.I2), Canine to first molar site (Mx.C to M1), Lateral incisor-central incisor (Mx.I2.I1), and Canine to central incisor site (Mx.C to I1). In the mandible, only two classifications are described which are Lateral incisor-canine (Mn.I2.C) and Canine transmigrated/erupted (Mn.C.transerupted $)^{70}$. Another classification was suggested for maxillary transposition, between the third molar and second molar (Mx.M3M2) ${ }^{71}$.

In the identification of this condition, a distinction should be made between a complete and an incomplete transposition. A complete transposition occurs where both crowns and the entire root structures of the involved teeth are found in their transposed positions. Incomplete transposition is also called "pseudo" or "partial" transposition because the crowns may be transposed while the root apices remain in their normal positions or the crowns may be in the correct order while the root apices are transposed. The involved teeth overlap and their long axes cross each other ${ }^{72}$.

Many developmental dental anomalies may be caused by genetic and environmental factors, especially during the morpho-differentiation or histo-differentiation stages of development ${ }^{70}$. The etiology of TT is multifactorial; both genetic and environmental factors can play important roles in its development. The nature of recommended treatment for TT is orthodontic, since many cases are diagnosed during orthodontic assessment ${ }^{1}$.

The aim of this study was to report two cases of TT and review the literature of cases published in English language on this condition.

\section{CASE REPORT}

During a routine clinical examination, bilateral TT was observed between the first and second mandibular molars in a 26-year old male patient (patient 1). Giroversion of the mandibular first molars was also observed (figure 1A and B). Moreover, clinical and radiographic examinations demonstrated missing third mandibular molar of the right side (figure $1 \mathrm{E}$ and $\mathrm{H}$ ), though the patient denied any previous dental extraction, which led to the hypothesis of agenesis.

From these observations, we diagnosed TT. Based on the knowledge of genetic factors associated 
with TT, we conducted clinical evaluations on the direct relatives of the patient; TT was observed in his mother.

The second patient (patient 2), a 56-year-old-woman, presented with unilateral transposition between the left mandibular molars, without giroversion (figure 2B). The transposition was characterized by the presence of three vestibular cusps in the tooth located as the second left mandibular molar. However, three vestibular cusps are characteristic of the first molar. On clinical examination, the absence of right maxillary canine, first left maxillary premolar, and first right mandibular molar, was observed. The patient reported a history of few tooth extractions when she was younger, but she could not recall which teeth. Retained maxillary left canine was observed on the panoramic radiograph. The patient was informed about her diagnosis and referred to the oral and maxillofacial surgery department.

Both patients did not have previous knowledge of the TTs. Hence, they declined any treatment, since this anomaly did not influence their quality of life.

\section{DISCUSSION}

TT is considered a rare dental anomaly ${ }^{73}$ and has been described as an interchange in the position of two permanent teeth within the same quadrant of the dental $\operatorname{arch}^{1}$. The prevalence of this anomaly varies according to the sample studied, but it remains low in most literature reports ${ }^{69}$. Clinical relevance of TT are possible disorders in dental occlusion, level of dental crowding, aesthetics and position of the roots. Besides that, this anomaly can be associated with other dental
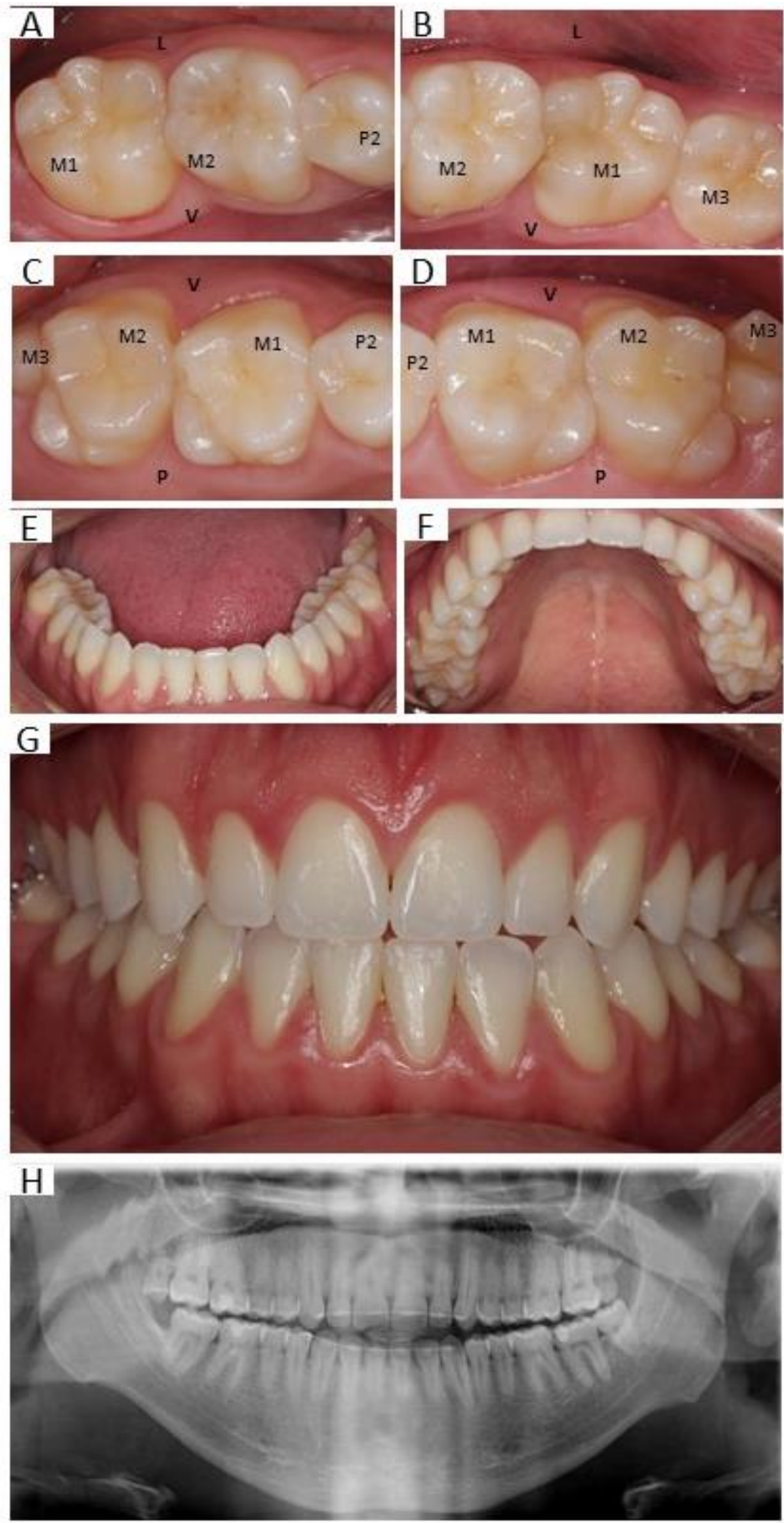

Figure 1 - (Patient 1): A) Tooth transposition between first and second right mandibular molars. In addition, giroversion of first molar can be observed. B) Tooth transposition between first and second left mandibular molars. In addition, giroversion of first mo molar can be observed. C) Occlusal view of the left maxillary molars. D) Occlusal view of the right maxillary molars. E) Mandibular arch view. F) Maxillary arch view. G) Occlusion of the upper and lower arches showing aesthetic and functional harmony. H) Panoramic Radiography showing the absence of third mandibular right molar. 
anomalies teeth ${ }^{71,12,19}$.
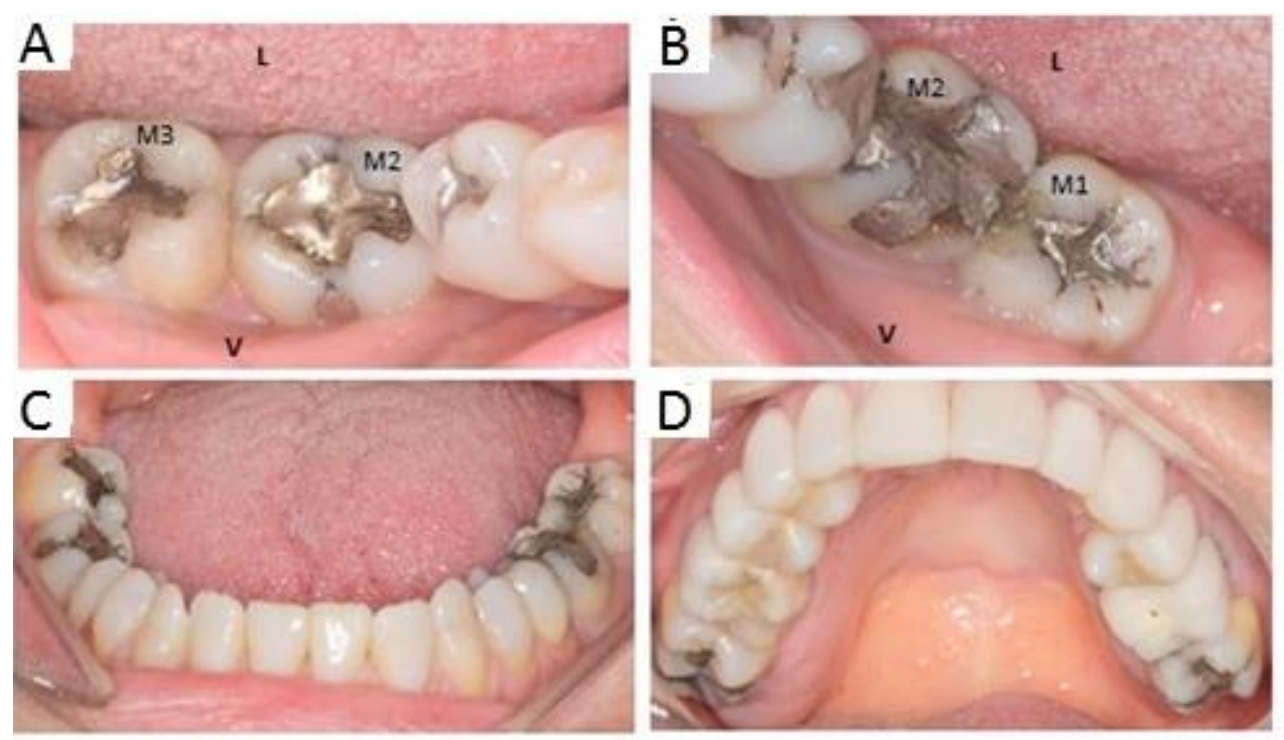

\section{$\mathrm{E}$}

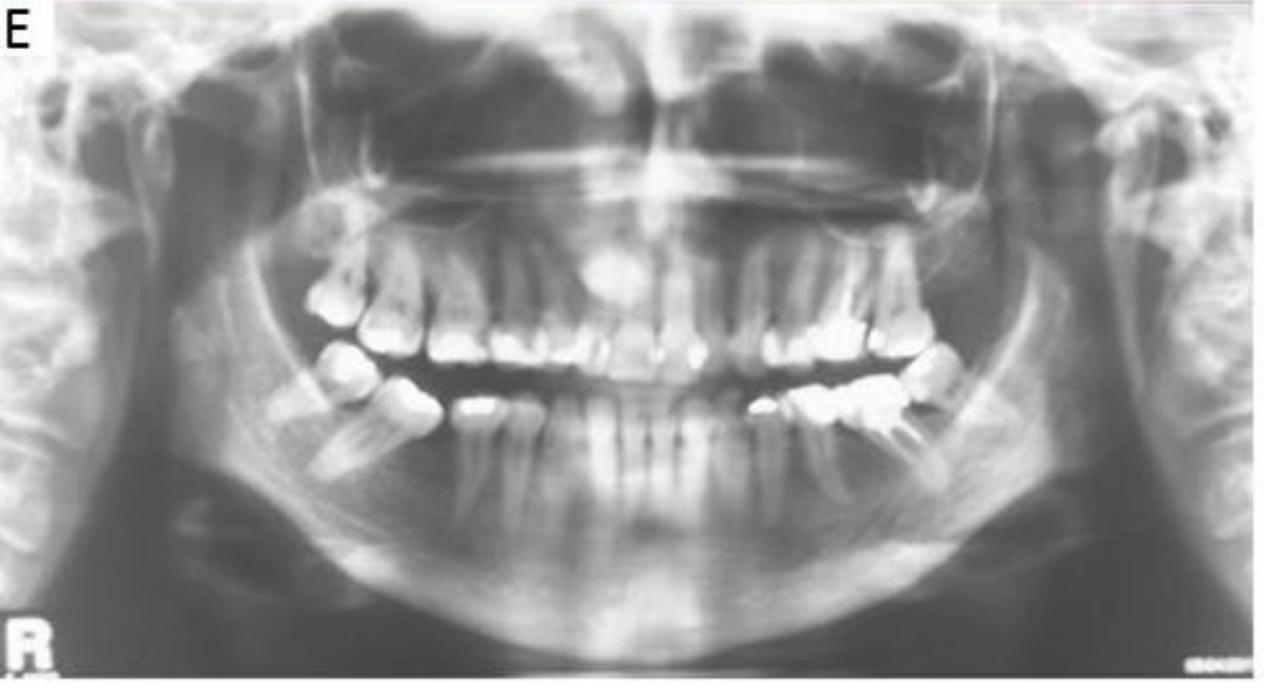

Figure 2 - (Patient 2): a) Occlusal view of the right mandibular molars and showing the absence of first mandibular right molar. b) Tooth transposition between first and second left mandibular molars. c) Mandibular arch view. d) Maxillary arch view. e) Panoramic Radiography.
It can be complete or incomplete. When it affects both the roots and crowns of the teeth, it is described as complete and when it affects only the crowns, it is said to be incomplete transposition ${ }^{16,60}$. Three database reviews in English literature revealed 62 articles published over the last 15 years, in which 153 clinical cases were described (table 1). Among these, only 12 described cases in mandible 6 ,12-14,21$, 23,40,54,60$ and only 1 case involved the first and second molars ${ }^{13}$. With this research it was possible to show the rarity of cases in the mandibular molars, which led to the elaboration of this report. Furthermore, an earlier case survey identified 60 cases of mandibular TT; however, none of these cases involved molars ${ }^{70}$.

In the literature, most of the reported TT cases have occurred in the maxilla, between the canine and first premolar, representing 94 cases (table 1 - figure 3). In both arches, unilateral TT is most prevalent and the occurrence of more than one TT in the same patient is rare66. Besides, TT can be associated with other dental anomalies, the most common being impacted canine, hypodontia and supernumerary teeth ${ }^{71,12,19}$. In our case report, patient 1 presented with mandibular bilateral TT, in addition to giroversion of the transposed molars and mandibular right third molar agenesis. Patient 2 presented with retained maxillary left canine.

In the literature survey performed during this study, 12 articles reported an association between TT and agenesis 3,4,9,11,13,14,17,20,54,55,62,64 but none described the occurrence of tooth giroversion. The reported frequency of the association between TT and agenesis in previous studies was around $37-40 \%{ }^{16,65}$. In addition, retained canine was one of the most common dental anomalies found in combination with TT (Table 1), and this may suggest a common etiological origin for these conditions.

In the review of literature, we analyzed the most common anomalies associated with TT. We found 56 cases associated with retained canine, 24 associated with impaction, 12 associated with 
hypodontia, 14 associated with microdontia, 1 associated with macrodontia, 11 associated with ectopic eruption; 13 associated with agenesis; 5 associated with dilacerations, 3 associated with supernumerary teeth, 1 associated with dens in dente, 1 associated with radiculomegaly and 16 with no associated anomaly, may have more than one associated (table 1).

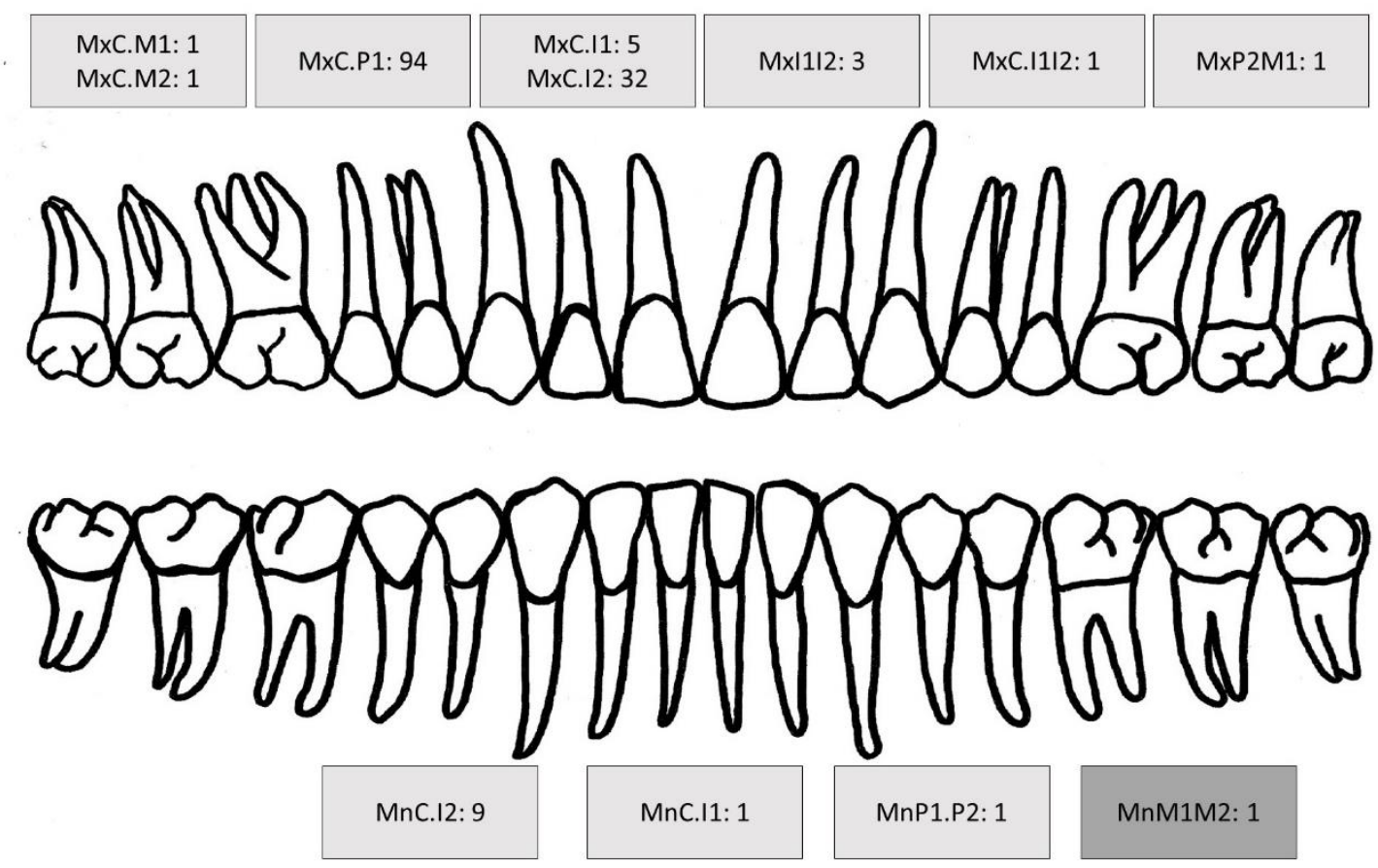

Figure 3 - Number of tooth transposition cases found in literature review. MnC.I2: Mandibular canine-lateral incisor; MnC.11: Mandibular canine-central incisor; MnP1.P2: mandibular first-second premolars; MnM1.M2: mandibular first-second molars; MxC.M1: maxillar : maxillary canine-first molar; MxC.M2: maxillary canine-second molar; MxC.P1: Maxillary canine-first premolar; MxC.11: maxillary canine-central incisor; MxC.12: Maxillary canine-lateral incisor; Mx11.12: maxillary central incisor-lateral incisor; MxC.11.12: Maxillary canine-central incisor-lateral incisor; MxP2.M1: maxillary second premolar-first molar.

The etiology of TT is uncertain and multifactorial. Both genetic and environmental factors have been cited as probable causes. Many theories have been propounded on the etiology of transposition. Accordingly, retained teeth, trauma, genetic predisposition, and ectopic eruption have all been suggested as the possible causes of transposition. The best argument for the genetic etiology of transposition would be a perturbation of the order of developing tooth follicles, since genes play an important role in patterning the dentition ${ }^{66}$. It is known that the development of the tooth depends on reciprocal interactions between the oral epithelium (derived from the ectoderm) and ectomesenchyme, which are mediated by the expression of several genes. The interchange of dental anlage during the developmental stages has been proposed as a cause of transposition ${ }^{13}$. Trauma, which presumably causes an "exchange" imposed by an external force, is another factor that been proposed as a cause of transposition ${ }^{13}$.

Another hypothesis for the genetic origin of dental transposition, wold be that that the anomaly would initiate with cell migration after the induction of cell groups at the onset of odontogenesis ${ }^{75}$. The epithelial cells would continue to migrate until they decoded the genetic information about the position in which they should develop. A mutation could cause abnormal dental position, and once these cells are fixed in position, they would begin to develop. Were found the frequency of transposition of canines and first pre-molars to be $8.5 \%$ in prehistoric populations; this further suggests a genetic origin of this dental anomaly $^{76}$. In addition, another studie showed transposition between the canines and first premolars in multiple members of the same family, further suggesting hereditary origins ${ }^{77}$. 
Based on the data collected, orthodontic treatment and extraction followed by prosthetic rehabilitation are the most common treatment procedures for TT. In our review, 55 of the articles analyzed, reported the use of orthodontic treatment for TT (Table 1). Moreover, in many of the cases reviewed, TT was identified during orthodontic treatment planning and examination. The goal of orthodontic treatment is to reestablish the normal position of dental elements in order to restore appropriate occlusion ${ }^{1}$. In clinical cases where TT affects the anterior teeth, orthodontic treatment can recreate the aesthetic harmony of the dentition'. However, when TT does not interfere with aesthetics or occlusion, treatment may not be required. In this case, the decision to opt for treatment should be determined by the patient, taking into account the benefits and consequences of available interventions, surgical or orthodontic ${ }^{1}$. The choice of the most appropriate treatment will be determined by factors such as occlusion, level of dental crowding, aesthetics, position of the roots, and patient specific needs.

Often, the extraction of some dental element is necessary for orthodontic treatment in order to make room for adequate repositioning of the teeth. Patient 1 reported having undergone orthodontic treatment for 7 years for a rather "wrong" dentition. Few years later, maxillary and mandibular dental containments were placed. Previous radiographs and the orthodontic records of the patient were not available in order to better analyze the dental condition prior to the orthodontic treatments.

\section{CONCLUSIONS}

TT is a dental condition that rarely involves mandibular molars. It is extremely rare and poorly documented in the literature. We hope that this report will help to improve the clinical knowledge about this anomaly.

In this report, we suggest a new categorization for dental transposition, Mn.M1.M2, represented by the transposition between the first and second mandibular molars. Our report documents two cases of this anomaly and we found another case during the literature review13. 


\begin{tabular}{|c|c|c|c|c|c|c|c|c|}
\hline AUTHOR & CASES & GENDER & AGE & LOCALIZATION & TEETH & SIDE & OTHER ANOMALY & TREATMENT \\
\hline Al-Mutawa, $\mathbf{2 0 0 3}^{3}$ & 1 & $\mathrm{~F}$ & 17 & Mx & C.P1 & B & $\mathrm{Ag}$. & No \\
\hline Saldarriaga, $2003^{4}$ & 1 & $\mathrm{~F}$ & 13 & Mx & C.11 & $\mathrm{R}$ & Ag. EE & Orthod \\
\hline Takada, $2005^{5}$ & 1 & $\mathrm{M}$ & 11 & $M x$ & 11.12 & L & No & Orthod. \\
\hline Kensu,20056 & 1 & $\mathrm{~F}$ & 29 & $\mathrm{Mn}$ & C.I2 & $\mathrm{L}$ & No & No \\
\hline Kuroda, $2005^{7}$ & 1 & $\mathrm{~F}$ & 21 & Mx & C.P1 & L & No & Orthod. \\
\hline \multirow[t]{2}{*}{ Lewis, $2005^{8}$} & \multirow[t]{2}{*}{2} & $\mathrm{~F}$ & 9 & Mx & C.I2 & L & Dilacer & Orthod / Rest \\
\hline & & $\mathrm{F}$ & 8 & $M x$ & C.12 & L & Dilacer & Orthod / Rest \\
\hline Maia, $2005^{9}$ & 1 & $\mathrm{~F}$ & 9 & Mx & C.P1 & B & $\mathrm{Ag}$. & Orthod \\
\hline Oredugba, $2005^{10}$ & 1 & $\mathrm{~F}$ & 15 & Mx & C.12 & $\mathrm{R}$ & Hypodontia & Orthod. \\
\hline Türkkahraman, & 2 & $\mathrm{~F}$ & 10 & $M x$ & C.11 & L & $\mathrm{Ag} /$, Impac, & Orthod. \\
\hline $2005^{11}$ & & M & 44 & $M x$ & C.11 & L & & Orthod. \\
\hline Doruk, 2006'12 & 1 & M & 8 & $\mathrm{Mn}$ & C.12 & $\mathrm{R}$ & No & Orthod \\
\hline Grant, $2006{ }^{13}$ & 1 & M & 12 & $\mathrm{Mn}$ & M1M2 & $\mathrm{R}$ & Ag. & No \\
\hline Suprabha, 2006 ${ }^{14}$ & 1 & $\mathrm{~F}$ & 14 & $\mathrm{Mn}$ & P1.P2 & $\mathrm{L}$ & Ankylosis / Ag & Orthod. \\
\hline Borrie, $2007^{15}$ & 1 & $\mathrm{M}$ & 7 & $\mathrm{Mx}$ & 11.12 & $\mathrm{R}$ & Macrodont / Supernumerary & Rest / Extraction \\
\hline $\begin{array}{l}\text { Capelozza Filho, } \\
2007^{16}\end{array}$ & 1 & $\mathrm{~F}$ & 9 & $\mathrm{Mx}$ & C.P1 & $\mathrm{R}$ & No & Orthod \\
\hline \multirow[t]{3}{*}{ Ciarlantini, $2007^{17}$} & 12 & $6 \mathrm{~F}$ & $11-52$ & Mx & 8 C.P1 & $6 \mathrm{R}$ & Retained canine / Ag & Orthod \\
\hline & & $6 \mathrm{M}$ & & & 4 C.I2 & $5 \mathrm{~L}$ & & \multirow[t]{2}{*}{ Extraction } \\
\hline & & & & & & $1 \mathrm{~B}$ & & \\
\hline Hägg, $2007^{18}$ & 1 & $\mathrm{~F}$ & 13 & Mx & C.P1 & $\mathrm{R}$ & $\mathrm{EE}$ & Orthod. \\
\hline Babacan, $2008^{19}$ & 1 & $\mathrm{~F}$ & 12 & Mx & C.P1 & B & No & Orthod \\
\hline \multirow[t]{2}{*}{ Bruno, 2008 ${ }^{20}$} & 1 & $\mathrm{~F}$ & 15 & $M x$ & C.P1 & $\mathrm{R}$ & $\mathrm{Ag}$ & Orthod \\
\hline & & & & & & & & Extraction \\
\hline \multirow[t]{3}{*}{ Sabri, 2008 ${ }^{21}$} & 9 & $7 \mathrm{~F}$ & $10-13$ & $3 \mathrm{Mn}$ & $6 \mathrm{C} .12$ & $6 \mathrm{~L}$ & Impac / EE / Retained canine & \multirow{3}{*}{$\begin{array}{l}\text { Orthod / } \\
\text { Extraction / } \\
\text { Rest }\end{array}$} \\
\hline & & $2 M$ & & $6 \mathrm{Mx}$ & 3 C.P1 & $3 \mathrm{~B}$ & & \\
\hline & & & & & & & & \\
\hline Almeida, $2009^{22}$ & 1 & $\mathrm{~F}$ & 10 & $\mathrm{Mn}$ & C.I2 & $\mathrm{B}$ & Impac & Orthod \\
\hline Canoglu, $2009^{23}$ & 1 & $\mathrm{~F}$ & 12 & $\mathrm{Mn}$ & C.12 & $\mathrm{R}$ & No & Orthod \\
\hline Giacomet, 2009²4 & 1 & $\mathrm{~F}$ & 10 & $\mathrm{Mx}$ & C.P1 & $\mathrm{R}$ & $\mathrm{EE}$ & Orthod \\
\hline Halazonetis, $2009^{25}$ & 1 & M & 12 & $M x$ & C.P1 & B & $\mathrm{EE}, /$ Impac & Orthod \\
\hline Ruellas, $2009^{26}$ & 1 & $\mathrm{~F}$ & 10 & $\mathrm{Mx}$ & C.12 & $\mathrm{L}$ & Impac / Dilacer & Orthod \\
\hline
\end{tabular}




\begin{tabular}{|c|c|c|c|c|c|c|c|c|}
\hline Vitale, $2009^{27}$ & 1 & $\mathrm{~F}$ & 8 & $\mathrm{Mx}$ & C.P1 & L & No & Orthod \\
\hline Asensi, $2010^{28}$ & 1 & $\mathrm{~F}$ & 7 & $\mathrm{Mx}$ & C.11.12 & $\mathrm{R}$ & Impac & Orthod \\
\hline Deepti, $2010^{29}$ & 1 & $\mathrm{~F}$ & 12 & $\mathrm{Mx}$ & C.12 & $\mathrm{R}$ & Impac & Orthod \\
\hline Kapoor, $2010^{30}$ & 1 & $\mathrm{~F}$ & 16 & Mx & C.P1 & B & $\mathrm{EE}$ & Orthod \\
\hline Ozan, 2010 31 & 1 & $\mathrm{~F}$ & 22 & $M x$ & C.P1 & L & No & Orthod \\
\hline Synodinos, $2010^{32}$ & 1 & $\mathrm{~F}$ & 9 & Mx & C.P1 & $\mathrm{L}$ & No & Orthod \\
\hline Cho, $2011^{33}$ & 1 & $\mathrm{M}$ & 14 & $M x$ & C.P1 & $\mathrm{L}$ & Retained canine & No \\
\hline Pair, 2011 ${ }^{34}$ & 1 & $\mathrm{~F}$ & 12 & $\mathrm{Mx}$ & C.12 & $\mathrm{L}$ & No & Orthod \\
\hline Uribe, $2011^{35}$ & 1 & $\mathrm{~F}$ & 25 & $\mathrm{Mx}$ & C.P1 & $\mathrm{R}$ & Radiculomegaly & Orthod \\
\hline \multirow[t]{5}{*}{ Cho, $2012^{36}$} & \multirow[t]{5}{*}{69} & \multirow[t]{2}{*}{$26 \mathrm{M}$} & \multirow[t]{5}{*}{$11-15$} & \multirow[t]{5}{*}{ Mx } & 55 C.P1 & $\mathrm{B} \quad(8$ in & Hypodontia (11 cases) & \multirow[t]{5}{*}{ No described } \\
\hline & & & & & 12 C.I2 & C.P1) & Microdontia lateral incisor (10) & \\
\hline & & \multirow[t]{3}{*}{$43 \mathrm{~F}$} & & & 1 C.I1 & & Impac (11) & \\
\hline & & & & & \multirow[t]{2}{*}{1 C.M1 } & $29 \mathrm{R}$ & Supernumerary (2) & \\
\hline & & & & & & $32 \mathrm{~L}$ & Retained canine (52) & \\
\hline Farret, $2012^{37}$ & 1 & $\mathrm{~F}$ & 14 & $\mathrm{Mx}$ & C.P1 & $\mathrm{R}$ & Impac & Orthod \\
\hline Kuril, $2012^{38}$ & 1 & $\mathrm{M}$ & 23 & $\mathrm{Mx}$ & C.P1 & $\mathrm{L}$ & No & Orthod / Rest \\
\hline Nishimura, 2012 ${ }^{39}$ & 1 & $\mathrm{~F}$ & 16 & $M x$ & C.P1 & $\mathrm{R}$ & Retained canine / EE & Orthod \\
\hline Sabuncuoglu, $2012^{40}$ & 1 & $\mathrm{~F}$ & 10 & $\mathrm{Mn}$ & C.12 & $\mathrm{L}$ & EE & Orthod \\
\hline Yadav, $2012^{41}$ & 1 & $\mathrm{~F}$ & 35 & $M x$ & C.12 & L & Microdontia & Protetic / Rest \\
\hline Cannavale, $2013^{42}$ & 1 & $\mathrm{~F}$ & 10 & $\mathrm{Mx}$ & P2M1 & $\mathrm{L}$ & $\mathrm{EE}$ & Orthod \\
\hline $\mathrm{Fu}, 2013^{43}$ & 1 & $\mathrm{~F}$ & 17 & $\mathrm{Mx}$ & C.12 & $\mathrm{L}$ & Impac & Orthod \\
\hline \multirow[t]{2}{*}{ Lin, $\mathbf{2 0 1 3}^{44}$} & \multirow[t]{2}{*}{1} & \multirow[t]{2}{*}{$\mathrm{F}$} & \multirow[t]{2}{*}{8} & \multirow[t]{2}{*}{$M x$} & \multirow[t]{2}{*}{ C.12 } & \multirow[t]{2}{*}{$L$} & \multirow[t]{2}{*}{ Dilacer / Impac } & Orthod./ \\
\hline & & & & & & & & Extraction \\
\hline Sachan, $2013^{45}$ & 1 & $\mathrm{M}$ & 19 & Mx & C.P1 & L & No & Orthod \\
\hline Selvaraj, $2013^{46}$ & 1 & $\mathrm{~F}$ & 36 & $\mathrm{Mx}$ & C.P1 & B & No & Orthod \\
\hline Ali, $2014^{47}$ & 1 & $\mathrm{~F}$ & 9 & $\mathrm{Mx}$ & C.11 & $\mathrm{L}$ & Dilacer & Orthod \\
\hline \multirow[t]{2}{*}{ Campbell, $2014^{48}$} & \multirow[t]{2}{*}{1} & \multirow[t]{2}{*}{ M } & \multirow[t]{2}{*}{7} & \multirow[t]{2}{*}{$M x$} & \multirow[t]{2}{*}{ C.I2 } & \multirow[t]{2}{*}{$\mathrm{L}$} & EE / Hypodontia / Microdontia / & Orthod \\
\hline & & & & & & & Impac & Extraction / Rrest \\
\hline \multirow[t]{2}{*}{ Cardoso, 2014 ${ }^{49}$} & \multirow[t]{2}{*}{1} & \multirow[t]{2}{*}{ M } & \multirow[t]{2}{*}{8} & \multirow[t]{2}{*}{$M x$} & C.P1 & B & No & Orthod \\
\hline & & & & & & & & Extraction \\
\hline Gebert, 2014 ${ }^{50}$ & 1 & $\mathrm{~F}$ & 12 & Mx & C.12 & L & Impac & Orthod \\
\hline Memon, 2014 ${ }^{51}$ & 1 & $\mathrm{~F}$ & 13 & Mx & C.P1 & B & No & Orthod \\
\hline Sholapurkar, $2014^{52}$ & 1 & M & 56 & Mx & 11.12 & $\mathrm{R}$ & Dens in dente & No \\
\hline Tripathi, $2014^{53}$ & 1 & $\mathrm{~F}$ & 19 & $\mathrm{Mx}$ & C.I2 & $\mathrm{L}$ & No & Protetic \\
\hline
\end{tabular}




\begin{tabular}{|c|c|c|c|c|c|c|c|c|c|}
\hline $\begin{array}{l}\text { Venkataraghavan, } \\
2014^{54}\end{array}$ & 1 & $\mathrm{M}$ & & 11 & $\mathrm{Mn}$ & C.12 & L & $\mathrm{Ag}$ & Orthod \\
\hline Di Palma, $2015^{55}$ & 1 & $\mathrm{~F}$ & & 7 & $M x$ & C.P1 & B & $\mathrm{Ag}$ & Orthod \\
\hline Dinoi, $2015^{56}$ & 1 & M & & 12 & $\mathrm{Mx}$ & C.P1 & $\mathrm{R}$ & Microdontia & Orthod \\
\hline Hsu, 2016 57 & 1 & $\mathrm{~F}$ & & 12 & Mx & C.12 & L & EE & Orthod \\
\hline \multirow[t]{2}{*}{ Lorente, $2016^{58}$} & 2 & M & & 12 & $M x$ & C.12 & B & No & \multirow[t]{2}{*}{ Orthod } \\
\hline & & $\mathrm{F}$ & & 15 & $M x$ & C.12 & L & No & \\
\hline Potrubacz, $2016^{59}$ & 1 & $\mathrm{~F}$ & & 7 & $M x$ & C.P1 & B & No & Orthod \\
\hline Di Venere, $2017^{60}$ & 1 & M & & 9 & $\mathrm{Mn}$ & C.I1 & $\mathrm{R}$ & No & Orthod \\
\hline Hekmatfar, $2017^{61}$ & 1 & $\mathrm{~F}$ & & 22 & $\mathrm{Mx}$ & C.M2 & $\mathrm{L}$ & Impac & No \\
\hline \multirow[t]{2}{*}{ Nabbout, $2017^{62}$} & \multirow[t]{2}{*}{2} & $\mathrm{~F}$ & & 13 & $M x$ & C.P1 & L & $\mathrm{Ag}$ & Orthod \\
\hline & & $\mathrm{F}$ & & 11 & $M x$ & C.P1 & $\mathrm{R}$ & No & Orthod \\
\hline Hwang, 2018 ${ }^{63}$ & 1 & $\mathrm{M}$ & & 12 & $M x$ & C.P1 & $\mathrm{R}$ & Microdontia & Orthod \\
\hline \multirow[t]{2}{*}{ Matsumoto, $2018^{64}$} & \multirow[t]{2}{*}{1} & \multirow[t]{2}{*}{$\mathrm{F}$} & & \multirow[t]{2}{*}{17} & \multirow[t]{2}{*}{$M x$} & \multirow[t]{2}{*}{ C.I2 } & \multirow[t]{2}{*}{$\mathrm{R}$} & $\mathrm{Ag}$ & Extraction \\
\hline & & & & & & & & Retained canine & Orthod \\
\hline \multirow[t]{3}{*}{ TOTAL } & \multirow[t]{3}{*}{153} & $\mathrm{~F}$ & $\mathrm{M}$ & & Mn 12 & & & & \\
\hline & & & & & Mx 141 & & & & \\
\hline & & 102 & 51 & & 153 & & & & \\
\hline
\end{tabular}




\section{References:}

1. Shapira Y, Kuftinec M. Tooth transpositions - a review of the literature and treatment considerations. Angle Orthod. 1989 Dec;59(4):271-6.

2. Nambiar S, Mogram S, Shetty S. Transposition of theeth: forensic perspective. J Forensic Dent SCi. 2014 Sept;6(3):151-3.

3. Al-Mutawa SA, Shyama M, Honkala E. Maxillary canine-to-first premolar bilateral transposition in a female with Down syndrome. A case report. Med Princ Pract. $2003 \mathrm{Jul} / \mathrm{Sept}$;12(3):193-6.

4. Saldarriaga JR, Patiño MC. Ectopic eruption and severe root resorption. Am J Orthod Dentofacial Orthop. 2003 Mar;123(3):259-65.

5. Takada K, Fukushima H, Watanabe S, Ishida M, Ogasawara H, Motokawa W. Occlusal guidance of two Kabuki make-up syndrome patients: case reports. J Clin Pediatr Dent. 2005 Jan;28(2):1138.

6. Kansu O, Avcu N. Mandibular lateral incisor-canine transposition associated with dental anomalies. Clin Anat. 2005 Sept;18(6):446-8.

7. Kuroda S, Kuroda Y. Nonextraction treatment of upper canine-premolar transposition in an adult patient. Angle Orthod. 2005 May;75(3):472-7.

8. Lewis B, Durning P, McLaughlin W, Nicholson PT. Canine transposition following trauma and loss of a central incisor: treatment options. J Orthod. 2005 Mar;32(1):11-9.

9. Maia FA, Maia NG. Unusual orthodontic correction of bilateral maxillary canine-first premolar transposition. Angle Orthod. 2005 Mar;75(2):266-76.

10. Oredugba FA. Hypodontia in an adolescent with the HbSC genotype: a case report. Int J Paediatr Dent. 2005 Nov;15(6):455-8.

11. Türkkahraman H, Sayin MO, Yilmaz HH. Maxillary canine transposition to incisor site: a rare condition. Angle Orthod. 2005 Mar;75(2):284-7.

12. Doruk C, Babacan H, Biçakçi A. Correction of a mandibular lateral incisor-canine transposition. Am J Orthod Dentofacial Orthop. 2006 Jan;129(1):65-72.

13. Grant JER, Abu Mezier N, Dibiase AT. Mandibular first and second molar tooth transposition: a case report. Int J Paediatr Dent. 2006 May;16(3): 227-9.

14. Suprabha BS, Pai SM. Ankylosis of primary molar along with congenitally missing first permanent molar. J Indian Soc Pedod Prev Dent. 2006 May;24(5):35-7.

15. Borrie F, Cairns A. A patient with a macrodont, transposition and supplemental tooth in the upper anterior segment: a case report. Dent Update. $2007 \mathrm{Jul} / \mathrm{Aug} ; 34(6): 352-4$.

16. Capelozza Filho L, Cardoso MA, An TL, Bertoz FA. Maxillary Canine-First Premolar Transposition. Angle Orthod. 2008 Sept;78(5):954-60.

17. Ciarlantini R, Melsen B. Maxillary tooth transposition: correct or accept? Am J Orthod Dentofacial Orthop. 2007 Sept;132(3):385-94.

18. Hägg U, Wong RWK, Tng TTH. Severe transposition, ectopic eruption, and orthodontic alignment: a long-term appraisal. World J Orthod. 2007 Fall;8:232-40.

19. Babacan H, Kiliç B, Biçakçi A. Maxillary Canine-First Premolar Transposition in the Permanent Dentition. Angle Orthod. 2008 Sept;78(5):954-60.

20. Bruno MB, Salomão MB, Vilella OV, Mucha JN. A New Spring for Correction of Maxillary Canine-Premolar Transposition. J Clin Orthod. 2008 May;42(5):303-7.

21. Sabri R, Zaher A, Kassem H. Tooth transposition: 
a review and clinical considerations for treatment. World J Orthod. 2008 Winter;9(4):303-18.

22. Almeida RC, Carvalho FA, Almeida MA, Capelli J Jr. Orthodontic management of a patient with impacted and transposed

23. Mandibular canines. World J Orthod. 2009 Winter;10(4):345-9.

24. Canoglu E, Kocaderli I, Turgut MD. Alignment of transposed mandibular lateral incisor and canine using removable appliances. Aust Dent J. 2009 Sept;54(3):266-70.

25. Giacomet F Araújo MT. Orthodontic correction of a maxillary canine-first premolar transposition. Am J Orthod Dentofacial Orthop. 2009 Jul;136(1):115-23

26. Halazonetes, DJ. Horizontally impacted maxillary premolar and bilateral canine transposition. Am J Orthod Dentofacial Orthop. 2009 Mar;135(3):380-9.

27. Ruellas ACO, de Oliveira AM, Pithon MM. Transposition of a canine to the extraction site of a dilacerated maxillary central incisor. Am J Orthod Dentofacial Orthop. 2009 Apr;135(4 Suppl):S133-9.

28. Vitale C, Militi A, Portelli M, Cordasco G, Matarese G. Maxillary canine-first premolar transposition in the permanent dentition. J Clin Orthod. 2009 Aug;43(8):517-23.

29. Asensi JC. Mixed unilateral transposition of a maxillary canine, central incisor, and lateral incisor. Am J Orthod Dentofacial Orthop. 2010 Apr;137(4 Suppl):S141-53.

30. Deepti A, Rayen R, Jeevarathan J, Muthu MS, Rathna PV. Management of an impacted and transposed maxillary canine. J Indian Soc Pedod Prev Dent. 2010 Jan/Mar;28(1):38-41.

31. Kapoor P. Transposition of bilateral maxillary canine and first premolar. Int J Orthod Milwaukee. 2010 Winter;21(4):37-41.

32. Ozan B, Muğlali M, Celenk P, Günhan O. Postpubertal nonfamilial cherubism and teeth transposition. J Craniofac Surg. 2010 Sept;21(5):1575-7

33. Synodinos PN, Polyzois I. Maxillary canine-first premolar transposition in the permanent dentition: treatment considerations and a case report. J Ir Dent Assoc. 2010 Dec/Jan 2011;56(6):264-7.

34. Cho SY. Ehlers-Danlos syndrome (classic type): report of a case presenting with an unusual dental anomaly. Prim Dent Care. 2011 Oct;18(4):167-70.

35. Pair J. Transposition of a maxillary canine and a lateral incisor and use of cone-beam computed tomography for treatment planning. Am J Orthod Dentofacial Orthop. 2011 Jun;139(6):834-44.

36. Uribe F, Davoody A, Nanda R. Orthodontic treatment of a transposed gigantic canine --a case report. J Orthod. $2011 \mathrm{Dec} ; 38(4): 282-9$.

37. Cho SY, Chu V, Ki Y. A retrospective study on 69 cases of maxillary tooth transposition. J Oral Sci. 2012 Jun;54(2):197-203.

38. Farret MM, Farret MM, Farret AM, Hollweg H. Unusual orthodontic approach to a maxillary canine-premolar transposition and a missing lateral incisor with long-term follow-up. Am $\mathbf{J}$ Orthod Dentofacial Orthop. 2012 Nov;142(5):690-7.

39. Kuril RB, Samuel R. A Novel Approach for Correction of Tooth Transposition. J Indian Orthod Soc. 2012 Jul/Sept;46(3):154-8.

40. Nashimura K, Nakao K, Aoki T, Fuyamada M, Saito K, Goto S. Orthodontic correction of a transposed maxillary canine and first premolar in the permanent dentition. Am J Orthod Dentofacial Orthop. 2012 Oct;142(4):524-33.

41. Sabuncuoglu FA, Karacay S, Erkan M. Orthodontic treatment of transposition of permanent mandibular lateral incisor and left canine in mixed dentition: a case report. Pediatr

Dent. 2012 Mar/Apr;34(2):e40-3. 
42. Yadav S, Sheorain AK, Madan N, Bajaj P. Esthetics with prosthetics in case of maxillary canine transposition: a clinical report. Niger J Clin Pract. 2012 Jan/Mar;15(1):108-11.

43. Cannavale R, Matarese G, Isola G, Grassia V, Perillo L. Early treatment of an ectopic premolar to prevent molar-premolar transposition. Am J Orthod Dentofacial Orthop. 2013 Apr;143(4):559-69.

44. Fu PS, Wang JC, Wu YM, Huang TK, Chen WC, Tseng YC et al. Unilaterally impacted maxillary central incisor and canine with ipsilateral transposed canine-lateral incisor. Angle Orthod. 2013 Sept;83(5):920-6.

45. Lin YT. Maxillary canine-to-maxillary incisor transposition. Pediatr Dent. 2013 Sept/Oct;35(5):408-10.

46. Sachan A, Chaturvedi TP. Orthodontic management of maxillary canine first premolar transposition - a conservative approach. Int J Orthod Milwaukee. 2013 Winter;24(4):5962.

47. Selvaraj D, Raja J, Prasath S. Interdisciplinary approach for bilateral maxillary canine: First premolar transposition with complex problems in an adult patient. J Pharm Bioallied Sci. 2013 Jul;5(Suppl 2):S190-4.

48. Ali Z, Jaisinghani AC, Waring D, Malik O. Transposition of maxillary canine to central incisor site: aetiology, treatment options and case report. J Orthod. 2014 Sept;41(3):233-44.

49. Campbell CM, DiBiase A., Fleming PS. Concomitant dilaceration, transposition, and intraosseous migration: report of a patient treated with maxillary canine-central incisor substitution. Am J Orthod Dentofacial Orthop. 2014 Oct;146(4):514-21.

50. Cardoso Mde A, Guedes FP, Paranhos LR, Garib DG, Capelozza Filho L. Preventive orthodontic management of tooth transposition. Int J Orthod Milwaukee. 2014 Winter;25(4):45-50.

51. Gebert TJ, Palma VC, Borges AH, Volpato LE. Dental transposition of canine and lateral incisor and impacted central incisor treatment: a case report. Dental Press J Orthod. 2014 Jan/Feb;19(1):106-12.

52. Memon S, Fida M. Bilateral maxillary canine-first premolar transposition in permanent dentition. J Coll Physicians Surg Pak. 2014 Aug;24(8):597-9.

53. Sholapurkar AA. Incisor transposition. Br Dent J. 2008 Jun;204(11):598.

54. Tripathi S, Singh RD, Singh SV, Arya D. Maxillary canine transposition - A literature review with case report. J Oral Biol Craniofac Res. 2014 May/Aug;4(2):155-8.

55. Venkataraghavan K, Athimuthu A, Prasanna P, Jagadeesh RB. Transposition of Mandibular Lateral Incisor-Canine (Mn.I2.C) Associated with Hypodontia: A Review and Rare Clinical Case. J Clin Diagn Res. 2014 Apr;8:ZE04-6.

56. Di Palma E, Di Giuseppe B, Tepedino M, Chimenti C. Orthodontic management of bilateral maxillary canine-first premolar transposition and bilateral agenesis of maxillary lateral incisors: a case report. Dental Press J Orthod. 2015 Mar/Apr;20(2):100-9.

57. Dinoi MT, Mummolo S, Monaco A, Marchetti E, Campanella V, Marzo G. Orthodontic treatment of the transposition of a maxillary canine and a first premolar: a case report. J Med Case Rep. 2015 Mar;9(48):1-5.

58. Hsu YL, Chang CH, Roberts WE. Canine-lateral incisor transposition: Controlling root resorption with a bone-anchored T-loop retraction. Am J Orthod Dentofacial Orthop. 2016 Dec;150(6):103950 .

59. Lorente T, Lorente C, Murray PG, Lorente P. Surgical and orthodontic management of maxillary canine-lateral incisor transpositions. Am J Orthod Dentofacial Orthop. 2016 Nov;150(5):876-85.

60. Potrubacz MI, Tepedino M, Chimenti C. Maxillary canine-first premolar bilateral transposition in 
a Class III patient: A case report. Angle Orthod. 2016 May;86(3):509-19.

61. Di Venere D, Nardi GM, Lacarbonara V, Laforgia A, Stefanachi G, Corsalini M et al. Early mandibular canine-lateral incisor transposition: case report. Oral Implantol. 2017 Apr/Jun;10(2): 181-9.

62. Hekmatfar S, Jafari K, Zadfatah F, Mousavi S. Maxillary canine-second molar transposition: A rare case report. J Dent Res Dent Clin Dent Prospects. 2017 Spring;11(2):131-4.

63. Nabbout F, Skaf Z, Hlayhel J. Maxillary tooth transposition: A report of two cases. Int Orthod. 2017 Sept;15(3):467-82.

64. Hwang S, Kim I, Jang W, Choi YJ, Chung CJ, Kim KH. A 15-year follow up of an orthodontic treatment including a lower incisor extraction and keeping the maxillary caninepremolar transposition. Angle Orthod. 2018 Aug 3. Doi: 10.2319/020118-93.1.

65. Matsumoto MAN, Stuani MBS. Tooth transposition: a multidisciplinary approach. Dental Press J Orthod. 2018 Jan;23(1):97-107

66. Laganà G, Venza N, Borzabadi-Farahani A, Fabi F, Danesi C, Cozza P. Dental anomalies: prevalence and associations between them in a large sample of non-orthodontic subjects, a crosssectional study. BMC Oral Health. 2017 Mar;11:17(1):62.

67. Ely NJ, Sherriff, M, Cobourne, MT. Dental transposition as a disorder of genetic origin. European Journal of Orthodontics. 2006 Apr;28(2):145-51.

68. Joshi MR, Bhatt NA. Canine transposition. Oral Surg Oral Med Oral Path 1971 Jan;31(1):49-54.

69. Papadopoulos, MA, Chatzoudi, M, Kaklamanos, EG. Prevalence of tooth transposition. Angle Orthod. 2010 Mar;80(2):275-85.

70. Peck S, Peck L. Classification of maxillary tooth transpositions. Am J Orthod Dentofacial Orthop. 1995 May;107(5):505-17.

71. Peck S, Peck L, Kataja M. Mandibular lateral incisor-canine transposition, concomitant dental anomalies, and genetic control. Angle Orthod.1998 Oct;68(5):455-65.

72. Ferrazzini G. Maxillary molar transposition. J Dent Child (Chic). 2002 Jan-Apr;69(13):73-6.

73. Chattopadhyay A, Srinivas K. Transposition of teeth and genetic etiology. Angle Orthod. 1996 Apr;66(2):147-52. 